\title{
Wiatrowały i wiatrołomy w lasach Nadleśnictwa Wałbrzych w świetle analizy danych z SILP w środowisku GIS oraz ocena efektów powierzchniowych procesu saltacji wykrotowej w Górach Suchych, Sudety Środkowe
}

\author{
Uprootings and wind broken trees in the Walbrzych Forest District in the light of SILP \\ database and GIS analysis, and evaluation of the surficial effects of tree uprooting in the \\ Suche Mountains, the Middle Sudetes Mountains
}

\author{
Łukasz Pawlik \\ Instytut Geografii, Uniwersytet Pedagogiczny im. Komisji Edukacji Narodowejw Krakowie; e-mail: lpawlik@up.krakow.pl
}

\begin{abstract}
Zarys treści: $\mathrm{W}$ artykule przedstawiono charakterystykę wiatrowałów i wiatrołomów powstałych w latach 2002-2011 w lasach Nadleśnictwa Wałbrzych. Dodatkowo wiatrowały, utożsamiane w geomorfologii z procesem saltacji (denudacji) wykrotowej, zostały szczegółowo scharakteryzowane na poligonie badawczym w Górach Suchych (Sudety Środkowe) obejmującym stoki Kopicy (786 m n.p.m.) i Czarnka (868 m n.p.m.), gdzie w latach 2009-2012 wykonano kartowanie geomorfologiczne, pomiar karp powalonych drzew i pomiar form akumulacyjnych powstałych w obrębie karp. Największe zniszczenia w drzewostanach Nadleśnictwa Wałbrzych powstały podczas orkanu Cyryl 18-19 stycznia 2007 r. Efekty tego orkanu były kartowane i analizowane w obrębie Kopicy i Czarnka. Do analiz regionalnych wykorzystano dane archiwizowane przez Lasy Państwowe w bazie SILP (System Informatyczny Lasów Państwowych). Kubaturę ( $\mathrm{w}^{3}{ }^{3}$ ) wykrotów i drzew złamanych przez silny wiatr analizowano w środowisku GIS na bazie mapy wektorowej Nadleśnictwa Wałbrzych. Następnie wykonano kartogramy zniszczeń w drzewostanach wyrażone kubaturą pozyskanych wiatrowałów i wiatrołomów na jednostkę powierzchni $\left(\mathrm{m}^{3} \mathrm{ha}^{-1}\right)$. W 149 przypadkach w pełni pomierzonych karp (ich szerokość, wysokość i miąższość), na 200 skartowanych, obliczono ich objętości, których średnia wartość wyniosła $4,2 \mathrm{~m}^{3}$. Na podstawie sporządzonych kartogramów stwierdzono, że największa intensywność procesu saltacji wykrotowej miała miejsce na stokach Czarnka. Jednak ze względu na pożar jaki w 2008 objął masę drewna zakumulowaną na jego stokach po orkanie Cyryl nie była możliwa pełna ocena efektów tego procesu. Jednocześnie stwierdzono znaczne przyspieszenie degradacji karp w tym miejscu w porównaniu do karp w obrębie Kopicy.
\end{abstract}

Słowa kluczowe: GIS, saltacja wykrotowa, wiatrowały, wiatrołomy, orkan Cyryl, Sudety

\begin{abstract}
In this paper we present a characteristic of uprootings and wind broken trees in the Wałbrzych Forest District between 2002 and 2011. Additionally, windthrows, which in geomorphology are commonly identified as a direct effect of the tree uprooting process, were analysed in detail within a research site in the Suche Mountains, the Middle Sudetes. The site covers the slopes of Kopica (786 m a.s.1.) and Czarnek (868 m a.s.1.) hills, where between 2009 and 2012 geomorphic mapping and measurements of the root plates of fallen trees and various depositional forms associated with them, were conducted. The most severe wind damage in the Wałbrzych Forest District was caused by a windstorm, called Kyrill, which occurred on the $18^{\text {th }}$ and $19^{\text {th }}$ January 2007. Its effects were mapped and analysed at the Kopica and Czarnek study sites. Additionally, for regional analysis information from SILP database was used (SILP - Information System of the State Forests National Forest Holding). The volume of uprootings and snapped trees, measured in $\mathrm{m}^{3}$, was analysed in GIS software with the use of a vector layer with polygons of the forested areas of the Wałbrzych Forest District. Subsequently, a set of choropleth maps was prepared, showing wind damage in the forests by means of the volume of windthrows and wind snapped trees per unit area ( $\mathrm{m}^{3}$ $\mathrm{ha}^{-1}$ ). In the study site, 149 root plates, out of 200 mapped, were fully measured (width, height and thickness) allowing calculation of their mean volume, which was $4.2 \mathrm{~m}^{3}$. Based on the choropleth maps we show that the highest intensity of tree uprooting took place on the Czarnek hillslopes. However, due to a 2008 fire which burnt the wood accumulated there after the Kyrill windstorm the full evaluation of the tree uprooting effects was constrained. At the same time the Czarnek site showed a significant speeding up of root plates degradation, as compared with the Kopica site.
\end{abstract}




\section{Wstęp}

Szkody w lasach powstają z powodu wielu różnych czynników - naturalnych zaburzeń genezy biotycznej i abiotycznej (Szwagrzyk 2000, Dobrowolska 2010). W tym opracowaniu szczególny nacisk położono na zaburzenia w lasach wynikłe z naporu silnego (huraganowego, $>30 \mathrm{~ms}^{-1}$ ) wiatru. Obserwacje w wielu regionach Europy wskazują, że wiatr jest najważniejszym czynnikiem abiotycznym wpływającym na poziom zniszczeń w lasach (Brázdil 1998, Peterson 2000, Schelhaas i in. 2003, Brázdil i in 2004, Minár $\mathrm{i}$ in. 2009). Biorąc pod uwagę ten czynnik, stopień naruszenia kondycji drzewostanów może zostać oceniony na podstawie ilości (kubatury) pozyskanego drewna w trakcie czyszczeń sanitarnych. Nie jest to oczywiście informacja pełna, ponieważ w trakcie prac leśnych część drzew z różnych względów nie jest pozyskiwana (z miejsc trudno dostępnych, drzewa w znacznym stopniu rozłożone itp.). Dane tego typu są jednak jedynymi danymi obejmującymi swoim zakresem wszystkie obszary zalesione w Sudetach.

W roku 2007 w całej Polsce zanotowano zniszczenia rzędu ok. 3,7 $\mathrm{mln} \mathrm{m}^{3}$ powalonych drzew $\left(64,5 \mathrm{mln} \mathrm{m}^{3} \mathrm{w}\right.$ Europie), co było bezpośrednią konsekwencją orkanu, który przeszedł nad Europą pomiędzy 14 a 18 stycznia 2007 r. (Fink i in. 2009, Gardiner i in. 2010, Pawlik 2012a, 2013a). Orkan, zwany Cyrylem, nie miał pod względem intensywności i spowodowanych zniszczeń swojego odpowiednika od czasu orkanów Lothar i Martin w 1999 r. Przykładowo we Francji zanotowano wtedy łącznie $176 \mathrm{mln} \mathrm{m}^{3}$ zniszczonych drzew (Gardiner i in. 2010). W Sudetach ostatni raz większe zniszczenia zanotowano w roku 1966, rzędu 0,8 $\mathrm{mln} \mathrm{m}^{3}$, głównie w Karkonoszach (Pawlik 2012b).

Głównym celem tego artykułu jest możliwie pełna charakterystyka procesu saltacji wykrotowej w oparciu o dane przestrzenne analizowane w środowisku GIS oraz dane zebrane podczas prac terenowych. Część wyników została już opublikowana (Pawlik 2013a, 2014), ale w tym opracowaniu zakres badań został rozszerzony o podejście przestrzenne w środowisku GIS, z wykorzystaniem danych gromadzonych przez Lasy Państwowe. Artykuł składa się z dwóch integralnych, choć różniących się założeniami metodycznymi części. Pierwsza z nich skupia się na analizie przestrzennej rozkładu zniszczeń w lasach Nadleśnictwa Wałbrzych. Analizowane zniszczenia w latach 2002-2011 spowodowane były głównie przez epizody silnego wiatru. Główny nacisk położono na dane z roku 2007, kiedy to w dniach 18-19 stycznia w całych Sudetach miały miejsce najpoważniejsze zniszczenia spowodowane orkanem Cyryl. Druga część artykułu opiera się na wynikach kartowania geomorfologicznego w obrębie wybranego poligonu badawczego w Górach Suchych. Kartowanie i pomiary objęły karpy drzew powalonych przez orkan Cyryl w 2007 r.

\section{Zakres definicyjny opracowania}

Pojęcia takie jak wywroty, złomy i posusz nie należą do tradycyjnej nomenklatury używanej w opracowaniach geomorfologicznych, dlatego też w tym rozdziale zostaną one krótko objaśnione. Zgodnie z Mała Encyklopedia Leśna (1991) wywroty (również wiatrowały, wykroty, wichrowały i powały) oznaczają drzewa powalone przez wiatr wraz z systemem korzeniowym, który zostaje wyniesiony powyżej poziom gruntu $\mathrm{w}$ postaci karpy (por. także Rojan, 2010). W ekologii lasu oraz w geomorfologii proces ten określany jest jako saltacja lub denudacja wykrotowa (Kotarba 1970, Gerlach 1976, Faliński, Falińska 1986, Pawlik 2009), a w szerszym znaczeniu jako saltacja biologiczna (Birot 1966). Termin ten implikuje skokowy transport pewnej objętości materiału glebowego w systemach korzeniowych powalonych drzew. Karpa zazwyczaj deponowana jest w pobliżu miejsca wyrwania (zagłębienia). W wyniku jej powolnej degradacji powstaje kopiec, który $\mathrm{w}$ parze $\mathrm{z}$ zagłębieniem i w ich większym nagromadzeniu tworzy morfologię wykrotową (Šamonil i in. 2010, Pawlik 2013b).

Złomy (również wiatrołomy, wichrołomy, połomy) stanowią drzewa złamane przez wiatr. Natomiast posusz oznacza drzewa obumierające lub obumarłe w wyniku różnych czynników stresowych. Największe znaczenie geomorfologiczne ma saltacja wykrotowa (Kotarba 1970, Dąbrowska 2009, Pawlik 2009, 2012b, Rojan 2010) i w tym opracowaniu proces ten będzie przedmiotem szczegółowej analizy w kontekście danych archiwizowanych przez Lasy Państwowe, oraz informacji pozyskanych w trakcie prac terenowych.

\section{Obszar badań}

Obszar badań obejmuje Nadleśnictwo Wałbrzych oraz Góry Suche leżące w jego obrębie. Góry Suche razem z Masywem Dzikowca i Lesistej Wielkiej budują pasmo Gór Kamiennych (ryc. 1), które geograficznie należą do Sudetów Środkowych. Jedną z ważniejszych cech Gór Suchych jest ubóstwo wód powierzchniowych, co było inspiracją do nadania im takiej nazwy (Jońca 1987), przy równocześnie dość gęstej sieci dolinnej (Migoń i in. 2010). Zbudowane są ze skał efuzywnych, głównie ryolitów i tufów ryolitowych wieku permskiego, które zalegają w superpozycji na skałach osadowych tego samego wieku (Awdankiewicz 1999).

Region pod względem geologicznym należy do niecki śródsudeckiej, budując jej północne skrzydło okalające centralną część niecki o przebiegu NW-SE. Pod względem reliefu i energii rzeźby pasmo to charakteryzuje się zaokrąglonymi grzbietami, głęboko wciętymi dolinami i raczej płytkimi (1-2 m) pokrywami stokowymi. Nachylenie stoków często przekracza $30^{\circ}$ (ryc. 2).

Pasmo Gór Suchych w całości należy do piętra regla dolnego, osiągając w najwyższym punkcie na szczycie Waligóry 936 m n.p.m. Ze względu na intensywną gospodarkę leśną, ale również zapotrzebowanie na drewno w kopalniach węgla kamiennego w Zagłębiu Wałbrzyskim, naturalne lasy regla dolnego zostały wycięte i zastąpione monokulturami świerka pospolitego (Picea 


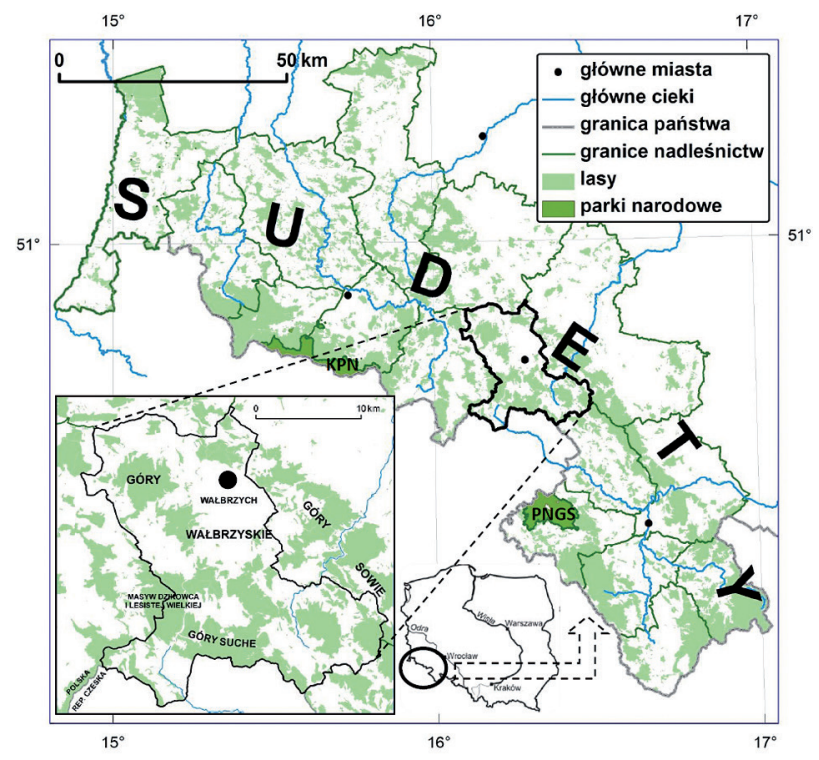

Ryc. 1. Obszary zalesione w granicach Sudetów Polskich (bez Gór Opawskich)

Na mapie wyróżniono Nadleśnictwo Wałbrzych czarna pogrubioną linią. KPN - Karkonoski Park Narodowy, PNGS Park Narodowy Gór Stołowych

Fig. 1. Forested parts of the Polish Sudetes Mountains (excluding Opawskie Mts.)

The Wałbrzych Forest District is marked by a black bolded line. KPN - Karkonosze National Park, PNGS - Stołowe Mountains National Park

abies). Takie naruszenie drzewostanów nie objęło prawdopodobnie całego obszaru Gór Suchych, gdyż jeszcze na niemieckiej mapie topograficznej z roku 1936 (arkusz Friedland, skala 1:25 000) wszystkie lasy na wschód od Sokołowska oznaczone zostały sygnaturą lasów mieszanych (niem. Mischwald). Obecnie świerk pokrywa 70\% obszaru nadleśnictwa. Inne gatunki to m.in. buk (Fagus sylvatica, 15\%), dąb (Quercus), klon jawor (Acer pseudoplatanus) i jesion (Fraxinus), zajmujące łącznie $8 \%$ powierzchni (Plan urzadzania lasu dla Nadleśnictwa Watbrzych, 2009).

Miejsce szczegółowych analiz i pomiarów terenowych obejmuje obszar położony na północnym stoku Ko- picy (786 m n.p.m.) i południowym stoku Czarnka (868 m n.p.m., niem. Der Schwarze Berg) (ryc. 2 i 3). Powierzchnia poligonu badawczego wynosi ok. 6 ha. Oba wzniesienia dzieli głęboko wcięta dolina Sokołowca Małego, którego źródła znajdują się na stokach Kopicy. Poligon ten wybrano ze względu na prawie całkowite zniszczenie drzewostanu w obrębie obu kulminacji i ich stoków. Dodatkowo nagromadzona masa zniszczonych drzew na Czarnku uległa pożarowi w 2008 r., co w znaczny sposób przyspieszyło degradację karp powalonych drzew w obrębie tej części poligonu.

Wzniesienie Kopica na niemieckiej mapie topograficznej w skali 1:25 000, arkusz Friedland, nosi nazwę Scholzen Köppel i sięga 790 m n.p.m. Polska nazwa tej kulminacji nie jest jednoznaczna. Zgodnie $\mathrm{z}$ informacją na portalu Geoportal.gov.pl tą samą nazwą na mapie topograficznej określa się graniczne wzniesienie na SE od Góralca (również określany jako Garniec), sięgające 803 m n.p.m. Na potrzeby tego opracowania przyjęto jej położenie wg mapy niemieckiej.

Według danych taksacyjnych z roku 1999 obszar badań na Czarnku i Kopicy zajmował drzewostan o charakterze monokultury świerka (100\%) o średnim wieku 115 lat (pododdział $270-$ d) i 90 lat (pododdział 265 -f).

\section{Metody i źródła danych}

Podstawowym źródłem danych z lat 2002-2011 była baza stworzona w ramach Systemu Informatycznego Lasów Państwowych (SILP). W bazie tej gromadzone są informacje inwentaryzujące wszystkie drzewostany będące własnością Lasów Państwowych, m.in. takie cechy drzew jak pierśnica (średnica pnia na wysokości klatki piersiowej dorosłego człowieka, ok. 1,3 m), wiek, wysokość, gatunek, zadrzewienie i wiele innych. W przypadku katastrofalnych wiatrowałów i wiatrołomów zniszczone drzewa są możliwie szybko pozyskiwane w ramach czyszczeń sanitarnych, a dane o kubaturze pozyskanego drewna trafiają do bazy SILP. W opisywanych w tym artykule badaniach szczególnie istotna była informacja na temat
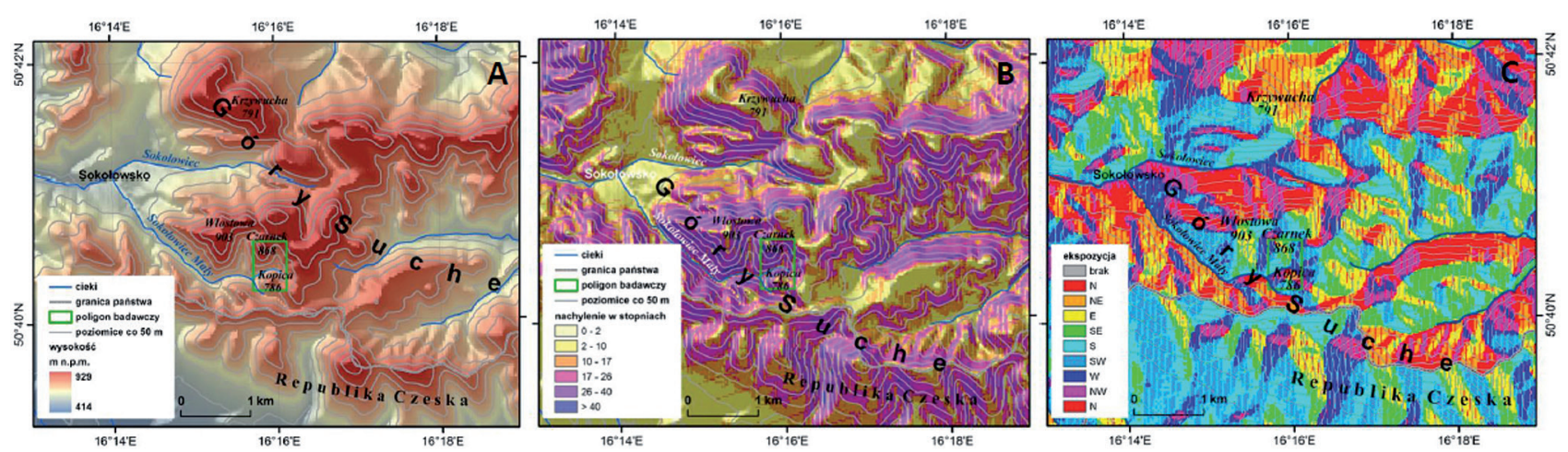

Ryc. 2. Główne cechy rzeźby w obrębie obszaru szczegółowych badań terenowych i jego sąsiedztwie

A - wyniesienie terenu w metrach n.p.m.; B - nachylenie powierzchni stoków w stopniach; C - ekspozycja stoków

Fig. 2. Main terrain characteristics of the area covered by detailed field mapping and around it

$\mathrm{A}$ - altitude in meters a.s.1.; $\mathrm{B}$ - slope inclination in degrees; $\mathrm{C}$ - slope exposition 
kubatury wiatrowałów (drewna pozyskanego w trakcie czyszczeń), ponieważ wskazywała ona na miejsca intensywnie przekształcone przez proces saltacji wykrotowej. Niestety baza ta nie uwzględnia ilości uszkodzonych drzew, co znacznie utrudnia możliwość interpretacji danych.

Kolejnym źródłem danych cyfrowych, opartych na modelu wektorowym, była mapa wydzieleń leśnych (Leśna Mapa Numeryczna) obejmująca swym zasięgiem Nadleśnictwo Wałbrzych. W Polsce jest to podstawowa jednostka podziału administracyjnego nadleśnictw o średniej powierzchni ok. 2,5 ha w przypadku Sudetów (ryc. 4). Każdy poligon ma przypisany unikalny adres leśny (np. 13-01-1-02-1-c-00), który pozwala na nadanie poszczególnym poligonom atrybutów ilościowych poprzez łączenie tabel w programie GIS. Dzięki temu, że każda informacja $\mathrm{w}$ bazie danych SILP przypisana jest do danego wydzielenia posiadającego adres leśny, informacja taka może być bezpośrednio wyeksportowana do programu GIS i poddana wizualizacji kartograficznej, np. w postaci kartogramu.

Procedurę wyznaczania cech abiotycznych dla powierzchni terenu zajętych przez lasy w Nadleśnictwie Wałbrzych również oparto na Leśnej Mapie Numerycznej (warstwa wektorowa z poligonami) na poziomie wydzieleń leśnych. Cechy tj. ekspozycja, nachylenie i wysokość n.p.m. otrzymano z NMT DTED 2 (numeryczny model terenu digital terrain elevation data) w rozdzielczości $25 \times 25 \mathrm{~m}$. Aby otrzymać pochodne NMT użyto opcji dostępnych w rozszerzeniu dla ArcGIS 9.3 DEM Surface Tools (Jenness 2011). Dla każdego z poligonów wyznaczono centroidę przy użyciu narzędzi Feature To Point dostępnych w pakiecie ArcGIS Data Management Tools. Mając wyznaczony punkt centralny dla każdego z poligonów na poziomie wydzielenia leśnego użyto opcji Intersect Point Tool dostępnym w rozszerzeniu Hawth's Analysis Tools (Beyer 2004), tak aby dla każdego punktu uzyskać atrybuty w postaci pochodnych NMT: ekspozycji, nachylenia i wysokości n.p.m. Cechy te uśredniano w granicach poligonów przy pomocy narzędzia Zonal Statistics. Dane otrzymane w postaci tabeli atrybutów były następnie eksportowane w pliku dBase i analizowane w programie Excel 2010. Pochodne NMT odnoszono do ważonej kubatury drewna pozyskanego z wiatrowałów i wiatrołomów w roku 2007, wyrażonej $\mathrm{w} \mathrm{m}^{3} \mathrm{ha}^{-1}$, i przedstawiono w postaci wykresów punktowych i radarowych.

Podobna procedura została zastosowana do cech biotycznych drzew, tj. pierśnicy, wieku i wysokości. Dane te pochodzą z prac urządzeniowych prowadzonych przez Biuro Urządzania Lasu i Geodezji Leśnej z siedzibą w Brzegu. Aby dane te można było analizować na podstawie mapy wektorowej, pod uwagę wzięto jedynie gatunek panujący w danym wydzieleniu. Jednocześnie nie oznacza to, że jego udział zawsze przekraczał 50\% (np. 40\% udziału świerka, 30\% buka i 30\% brzozy).

Ocena wizualna zniszczeń w drzewostanach możliwa była do przeprowadzenia poprzez porównanie ortofoto- map w bliskiej podczerwieni z lat 2004 i 2007. Ze względu na dzielący je interwał czasu dodatkowo wnioskowanie oparto na danych numerycznych o wykrotach i wiatrołomach dla każdego roku gospodarczego. Wynikało to z założenia, że nie wszystkie obserwowane na zdjęciu z roku 2007 partie wylesione powstały w trakcie orkanu Cyryl. W tym celu sporządzono kartogram zbiorczy dla lat 2006-2009 z łączną kubaturą ( $\left.\mathrm{m}^{3}\right)$ drzew powalonych i złamanych w odniesieniu do powierzchni (ha), oraz kartogram dla roku 2007, ale w podziale na wiatrowały i wiatrołomy $\left(\mathrm{w} \mathrm{m}^{3} \mathrm{ha}^{-1}\right)$. W trakcie sporządzania map tematycznych przyjęto podział na cztery klasy zniszczeń, przy czym na tle wartości zniszczeń pokazano tylko najwyższą klasę > $10 \mathrm{~m}^{3} \mathrm{ha}^{-1}$ (Bruchwald, Dmyterko 2010, 2012).

Kolejną metodą było kartowanie geomorfologiczne form mikrorzeźby stoku powstałych w wyniku procesu saltacji wykrotowej na wybranym poligonie badawczym (Kopica i Czarnek). Formy wykrotowe powstały podczas orkanu Cyryl w styczniu 2007 r., a kartowanie wykonano w latach 2009-2012. Do prac terenowych użyto odbiornik GPS, kompas geologiczny i taśmę mierniczą. W terenie przeprowadzono opis jakościowy oraz pomierzono główne cechy morfometryczne form. Na podstawie głównych wymiarów karp (wysokości, szerokości, miąższości) obliczono ich objętość. Opis sposobu pomiaru oraz obliczania objętości karp i zagłębień znajduje się w szeregu poprzednich opracowaniach różnych autorów (Dąbrowska 2009, Rojan 2010, Pawlik 2013c). Dodatkowo wykonano pomiary form akumulacyjnych i fragmentów skalnych budujących karpy. Na podstawie kierunku zalegania karp powalonych drzew wnioskowano natomiast o kierunku dominującego wiatru w trakcie orkanu Cyryl w tym regionie.

\section{Rezultaty}

\section{Wyniki analiz - przeksztalcenia drzewostanów}

Na przestrzeni lat 2002-2011 szkody zanotowane w Nadleśnictwie Wałbrzych były największe w 2007 r., jako bezpośrednie następstwo pojawienia się orkanu Cyryl 18-19 stycznia tego samego roku (ryc. 3). Jedynie w 2006 r. wiatrołomy (złomy) wyraźnie przeważały nad wiatrowałami (wywrotami), a konsekwencją dużych zniszczeń w roku 2007 była znaczna ilość drzew nieuprzątniętych, które w 2008 r. pozyskano jako posusz. Jak prawie w całych Sudetach, również tutaj zniszczeniu uległ głównie świerk. Nadleśnictwo Wałbrzych było jednym z trzech nadleśnictw sudeckich (obok nadleśnictw Kamienna Góra i Jugów) najbardziej poszkodowanych w wyniku przejścia orkanu Cyryl (Pawlik 2012a) (ryc. 4). Ze względu na wysokość obszaru oraz obecny zasięg regla dolnego główne zniszczenia koncentrowały się w pasie wysokości od 400 do 800 m n.p.m. (ryc. 7a). Jest to zarazem typowy pas zniszczeń wyodrębniony na podstawie danych z Republiki Czeskiej (Brázdil 1998), pasa gór południowej Polski (Jewuła 1974), w tym Sudetów (Pawlik 2012a). 


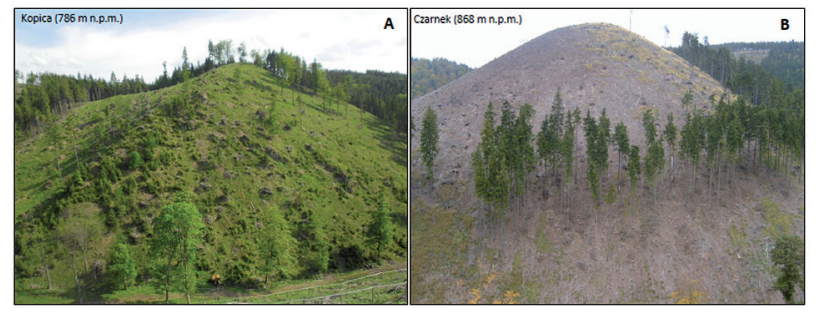

Ryc. 3. Widok na stoki kulminacji Kopicy i Czarnka będące miejscem szczegółowych badań terenowych

Fig. 3. General view of the sites of detailed field mapping on the hillslopes of Kopica and Czarnek

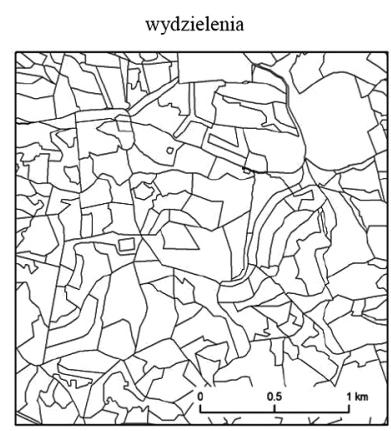

liczba $\mathrm{n}=92799$ max. powierzchnia $=58$ ha średnia powierzchnia $=2,5 \mathrm{ha}$

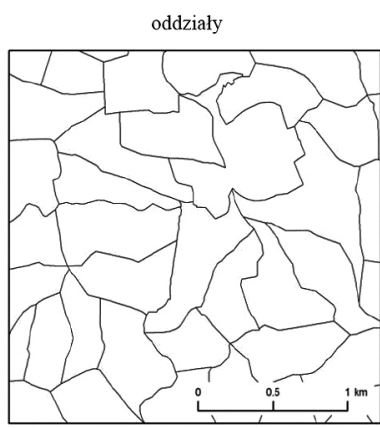

liczba $\mathrm{n}=10059$ max. powierzchnia $=99,6$ ha średnia powierzchnia $=23,4$ ha
Ryc. 4. Fragmenty mapy wektorowej nadleśnictw na różnym poziomie odniesienia (poligony w podziale na wydzielenia i oddziały leśne) użytej w prezentowanej analizie

Fig. 4. Samples of the forest vector map in different spatial units (polygons as smallest forest subareas) used in the study

Po odniesieniu kubatury zniszczeń do nachylenia stoków widoczna jest duża rozpiętość wartości, które swym zasięgiem obejmują powierzchnie o zróżnicowanych nachyleniach (ryc. 7b). Przeważają zniszczenia na powierzchniach nachylonych pod kątem $5-20^{\circ}$, które jednak dominują w tym obszarze (ryc. $2 \mathrm{~b}$ ). W przypadku wystawy stoków zdecydowanie przeważa sektor południowo-zachodni i południowy, co częściowo może mieć związek z kierunkiem uderzenia wiatru podczas orkanu (ryc. 7c). Na przeważający kierunek wiatru wskazują po-

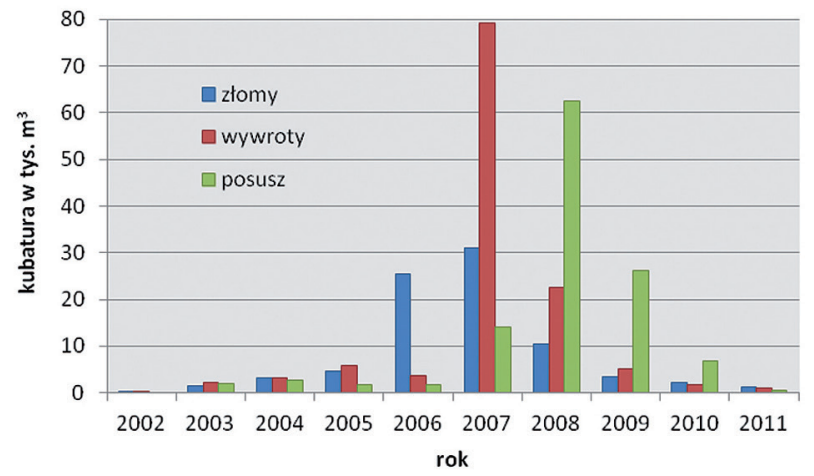

Ryc. 5. Struktura zniszczeń od silnego wiatru drzewostanów w Nadleśnictwie Wałbrzych w latach 2002-2011 (na podstawie bazy SILP)

Fig. 5. Forest damage structure due to strong wind in the Wałbrzych Forest District in 2002-2011 (based on SILP data)

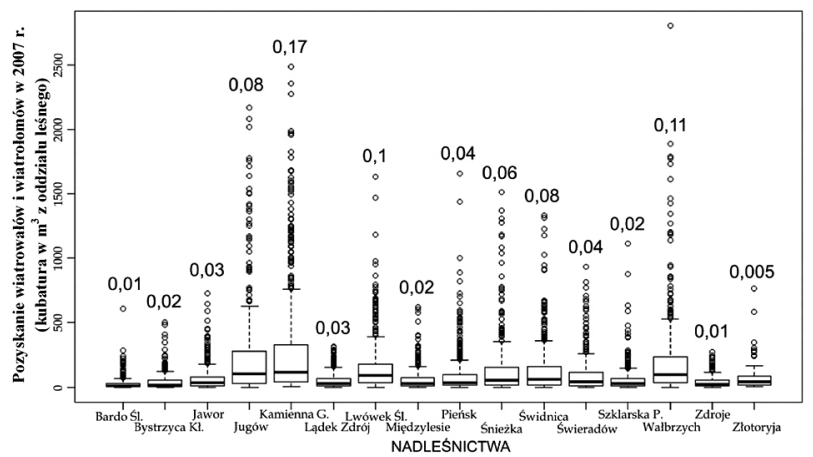

Ryc. 6. Kubatura wiatrowałów i wiatrołomów pozyskanych z nadleśnictw sudeckich w roku 2007 (Pawlik, 2012a, zmieniona)

Powyżej wykresów pudełkowych dla każdego z nadleśnictw podano całkowitą kubature pozyskanego drewna $\mathrm{w} \mathrm{mln} \mathrm{m}^{3}$. Punkty powyżej górnego ,wąsa” oznaczają wartości odstające powyżej 1,5 rozstępu ćwiartkowego

Fig. 6. The volume of uprootings and wind snapped trees withdrawn in 2007 from the area of Sudetic forest districts (after Pawlik, 2012a, modified)

Above each box plot for every forest district the total amount of damaged trees is given in millions of cubic meters. Black circles over the upper limit of box plots indicate outlined values which are defined as those over 1.5 IQR (interquartile range)

mierzone azymuty karp powalonych drzew, które koncentrują się w sektorze NE i E. Biorąc pod uwagę kierunek wiatru wynik ten pokrywa się $\mathrm{z}$ tendencją regionalną zanotowaną na przestrzeni wielu lat w Obserwatorium Meteorologicznym na Śnieżce (ryc. 8a i b). Drzewostan na stokach północnych mógł być bardziej osłonięty i przez to w mniejszym zakresie uszkodzony.

W przypadku cech biotycznych, wyodrębnionych z bazy danych w postaci pierśnicy, wieku i wysokości drzew, w relacji do kubatury zniszczeń nie wykazano istnienia wyraźnego związku (ryc. 9). Zniszczeniu uległy głównie drzewa o wysokości przekraczającej $20 \mathrm{~m}$ (ryc. 9A), pierśnicy rzędu 30-40 cm (ryc. 9B) i należące do starszych klas wieku, 60-80 lat (ryc. 9C). Drzewa młodsze o mniejszej wysokości mogły zostać uszkodzone w wyniku uderzenia większego sąsiedniego drzewa (por. Everham, Brokaw 1996). Niestety baza danych nie obejmuje tego typu informacji. Taki rozkład zniszczeń w relacji do wydzielonych cech prawdopodobnie jest silnie zależny od rodzaju danych podstawowych. Otrzymane informacje dotyczyły tylko gatunku dominującego $\mathrm{w}$ danym wydzieleniu leśnym.

W celu pełniejszego ujęcia zniszczeń zanotowanych w 2007 roku w obszarze badań, w obrębie stoków Czarnka i Kopicy, przeanalizowano rok 2006 oraz lata 20082009. Sporządzony kartogram zawiera następujące informacje (ryc. 10):

- kubatura zniszczeń $\left(\mathrm{m}^{3}\right)$ na jednostkę powierzchni wyrażona w ha (skala barwna);

- szkody powyżej $10 \mathrm{~m}^{3} \mathrm{ha}^{-1}$ (szrafura) określone jako 4 stopień regionalnego ryzyka zniszczeń wg Bruchwald, Dmyterko (2012) oraz IV strefa uszkodzenia drzewostanów (bardzo silne $>10 \mathrm{~m}^{3} \mathrm{ha}^{-1}$ ) (Jewuła, 1974). 

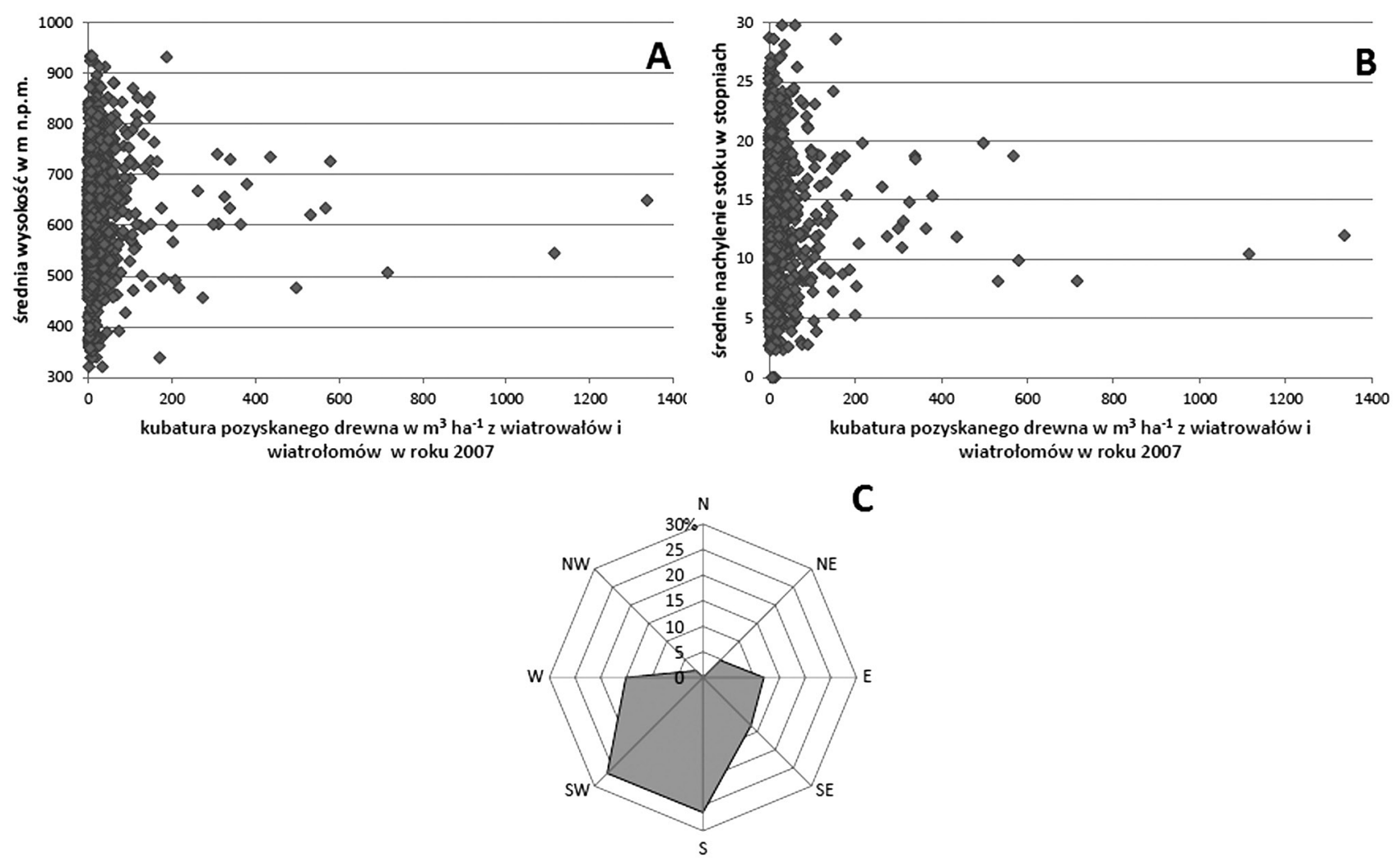

udział wiatrowałów i wiatrołomów $\left(w \mathrm{~m}^{3} \mathrm{ha}^{-1}\right)$ w relacji do uśrednionej ekspozycji

stoków

Ryc. 7. Relacja pomiędzy kubaturą wiatrowałów i wiatrołomów $\left(\mathrm{w} \mathrm{m}^{3} \mathrm{ha}^{-1}\right)$ a głównymi cechami rzeźby terenu (na podstawie danych z SILP, Leśnej Mapy Numerycznej i NMT DTED)

A - wysokość (m n.p.m.), B - nachylenie stoków $\left(^{\circ}\right), \mathrm{C}$ - ekspozycja

Fig. 7. Relationship between the volume of uprootings and broken trees $\left(\mathrm{in}^{3} \mathrm{ha}^{-1}\right)$ and the main terrain features (based on SILP database, Forest Digital Map and DTED DEM)

A - altitude (m a.s.1.), B - slope angle $\left({ }^{\circ}\right), \mathrm{C}-$ aspect
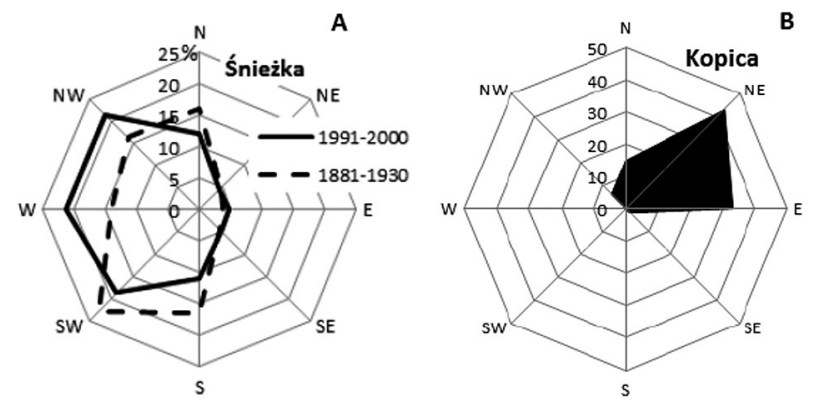

Ryc. 8. Przeważający kierunek zalegania pniaków karp powalonych drzew na poligonie Kopica w relacji do głównego kierunku wiatru zarejestrowanego w Obserwatorium Meteorologicznym na Śnieżce (1602 m n.p.m.) w latach 1881-1930 oraz 1991-2000 (dane dla Śnieżki na podstawie: Kosiba 1948 i Głowicki 2005)

Fig. 8. Dominant direction of fallen trees root plates within Kopica study site in relation to prevailing wind directions recorded at Śnieżka Meteorological Observatory (1602 m a.s.l.) in 1881-1930 and 1991-2000 (data for Śnieżka were based on: Kosiba 1948 and Głowicki 2005)
Z ryciny 10 wynika, że w przeciągu 4 lat (2006-2009) w każdym wydzieleniu zarejestrowano zniszczenia. Maksymalne wartości zanotowano na Czarnku, gdzie każdego roku osiągały one poziom określany jako „,bardzo silne” (pow. $10 \mathrm{~m}^{3} \mathrm{ha}^{-1}$ ).

Drzewostan na wschodnich stokach Czarnka został naruszony już w roku 2006 (4 stopień uszkodzenia), odmiennie niż północne stoki Kopicy, gdzie w tym samym roku zniszczeń nie zanotowano (ryc. 10). Pewnym sygnałem pojawienia się szkód w roku 2007 były natomiast zniszczenia na stoku południowo-zachodnim Kopicy. Mogły one doprowadzić do częściowego odsłonięcia drzewostanu na północnym stoku Kopicy i w konsekwencji jego zniszczenia przez orkan Cyryl. Rok 2007, tak jak w całym Nadleśnictwie Wałbrzych, był okresem drastycznych zmian w lasach. Praktycznie na całej długości doliny Sokołowca Małego doszło do przekształceń drzewostanów, przede wszystkich świerkowych z racji ich dominacji. Można przypuszczać, ze konfiguracja terenu wymusiła kanalizację przepływu powietrza, ponieważ zniszczenia wystąpiły na całej długości stoków, a miejscami w ich dolnym i środkowym segmencie. Czynnikiem, który w jakimś stopniu mógł warunkować skalę zniszczeń w górnej części potoku Sokołowca Małego było częścio- 

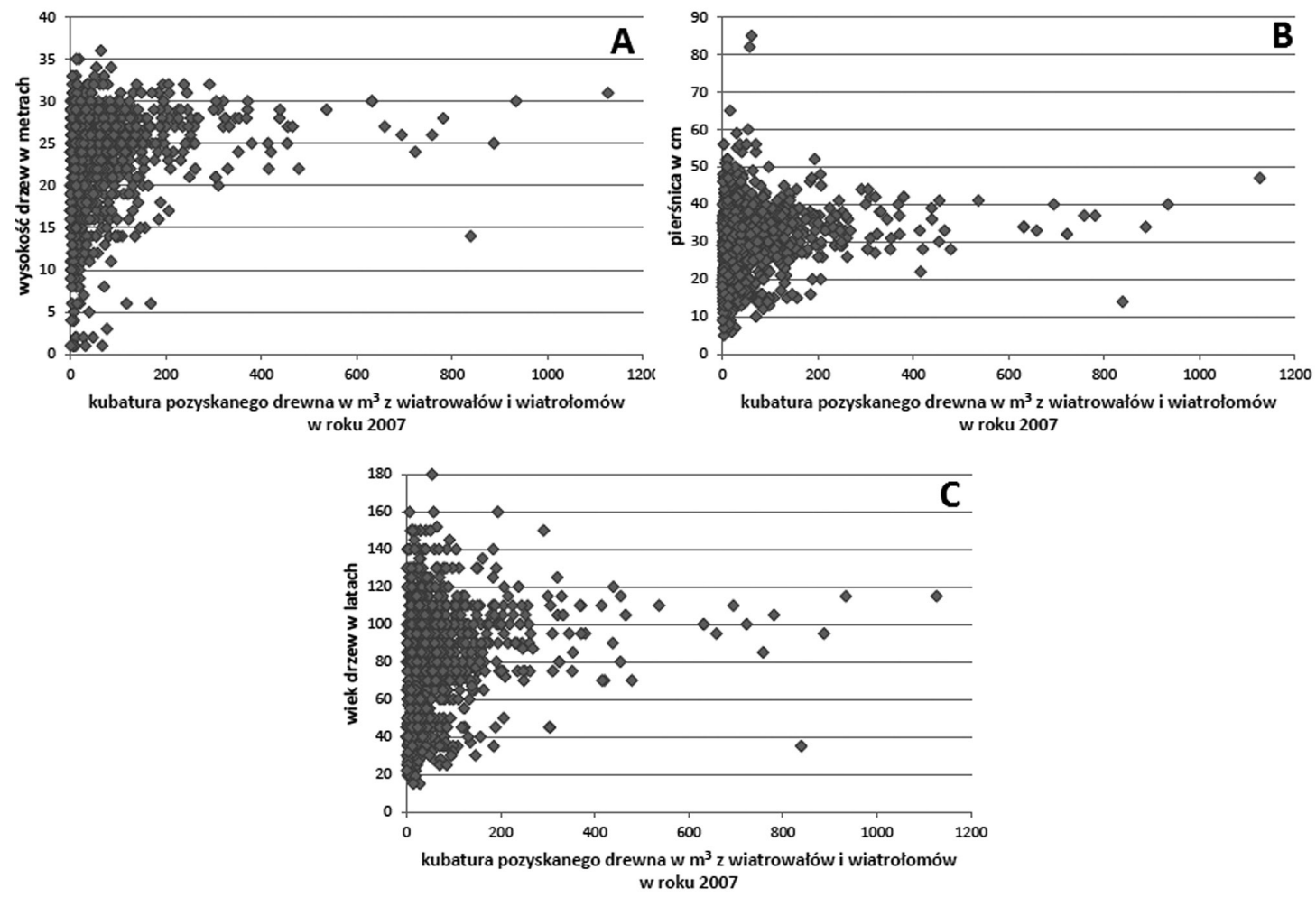

Ryc. 9. Relacja pomiędzy kubaturą wiatrowałów i wiatrołomów $\left(\mathrm{m}^{3}\right)$ a głównymi parametrami gatunku panującego w danym wydzieleniu leśnym (na podstawie bazy SILP, Leśnej Mapy Numerycznej i NMT DTED)

A - wysokość drzewa (m), B - pierśnicą (cm), C - wiek (lata)

Fig. 9. Relationship between the volume of uprootings and broken trees $\left(\mathrm{m}^{3}\right)$ and the main parameters of a dominant tree species for each basic forest unit (based on SILP database, Forest Digital Map and DTED DEM)

$\mathrm{A}$ - tree height $(\mathrm{m}), \mathrm{B}$ - diameter at breast height $(\mathrm{cm}), \mathrm{C}$ - age (years)

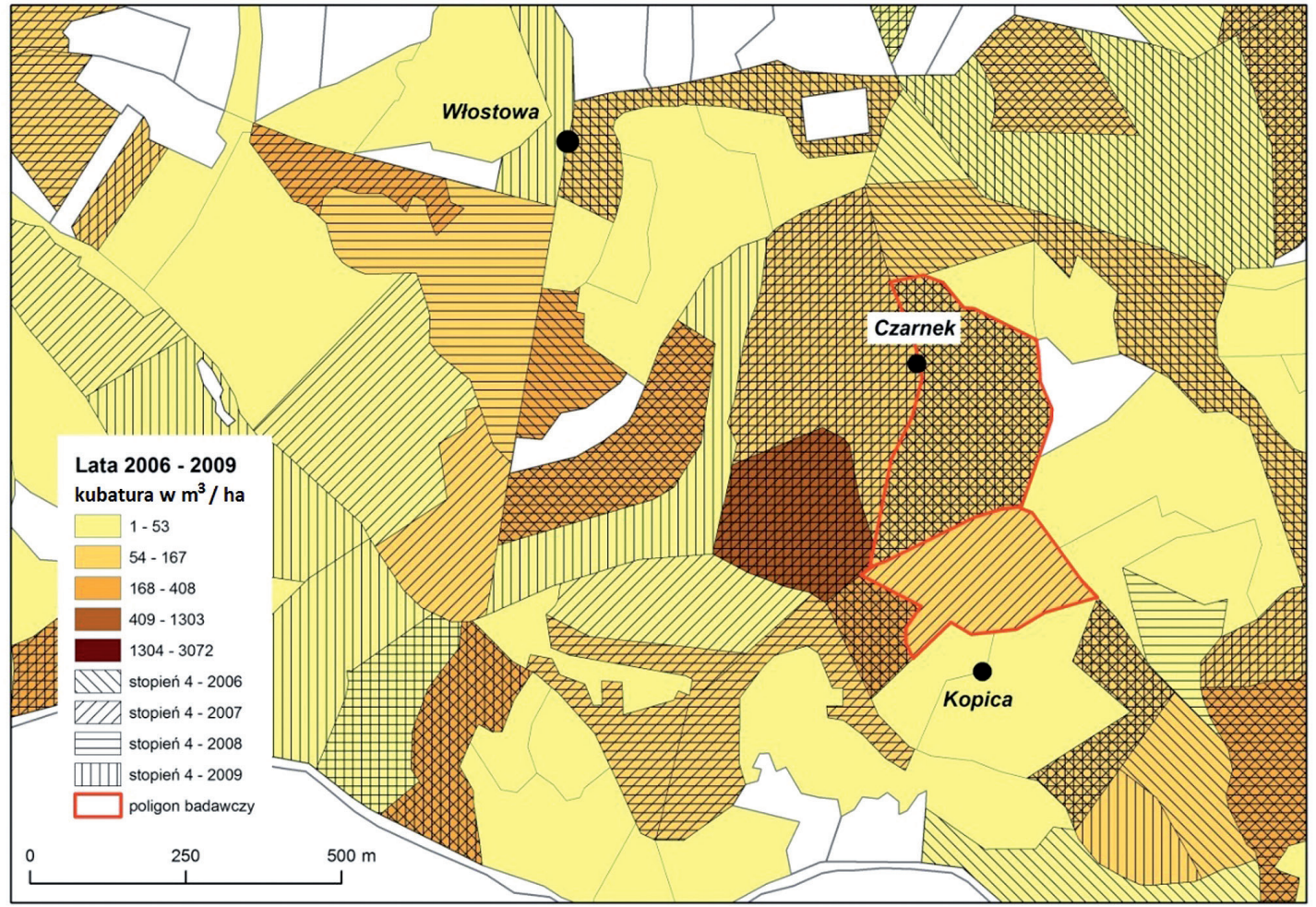

Ryc. 10. Fragment mapy zniszczeń drzewostanów Nadleśnictwa Wałbrzych w latach 2006-2009 (na podstawie Leśnej Mapy Numerycznej i bazy SILP)

Fig. 10. A map section of forest damage within the Wałbrzych Forest District with a summary of data for years 2006-2009 (based on Forest Digital Map and SILP database) 

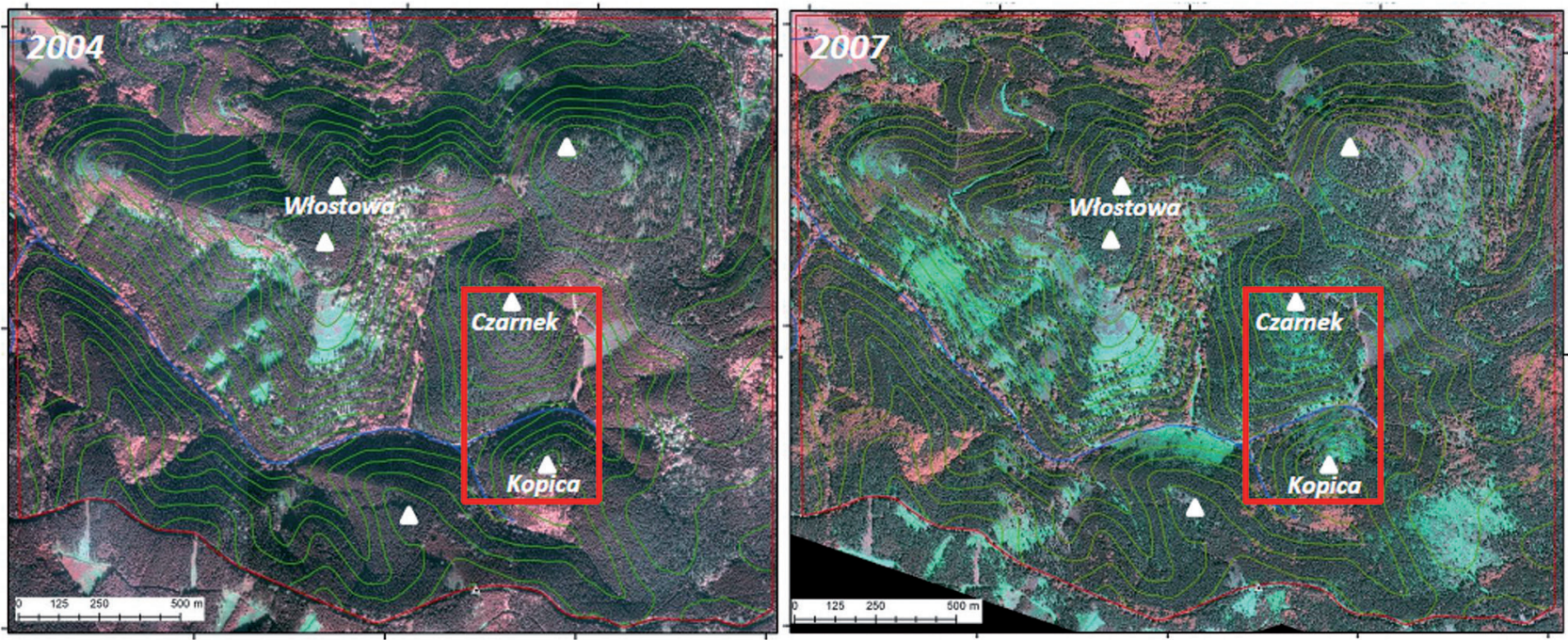

Ryc. 11. Porównanie ortofotomap okolic badań z lat 2004 i 2007 (dane udostępnione przez Nadleśnictwo Wałbrzych)

Fig. 11. Comparison of the orthophotomaps from 2004 and 2007 (data source: courtesy of Wałbrzych Forest District Directorate)

we wylesienie grzbietu i stoków Włostowej (ryc. 11), nie związanego z orkanem Cyryl, co prawdopodobnie przy północno-zachodniej składowej kierunku wiatru podczas orkanu Cyryl i braku tarcia strug powietrza o zwarty okap drzewostanu, mogło doprowadzić do większych szkód na wschód od tego masywu. Jednocześnie głównym czyn- nikiem była dominacja świerka jako gatunku budującego drzewostan i jego niekorzystna struktura (jednopiętrowe i jednowiekowe monokultury). Niektóre wyniki badań wskazują, że drzewostany mieszane są bardziej odporne na uszkodzenia od wiatru (np. Everham, Brokaw, 1996). Warto zaznaczyć, że w roku 2007 na Czarnku zanotowa-

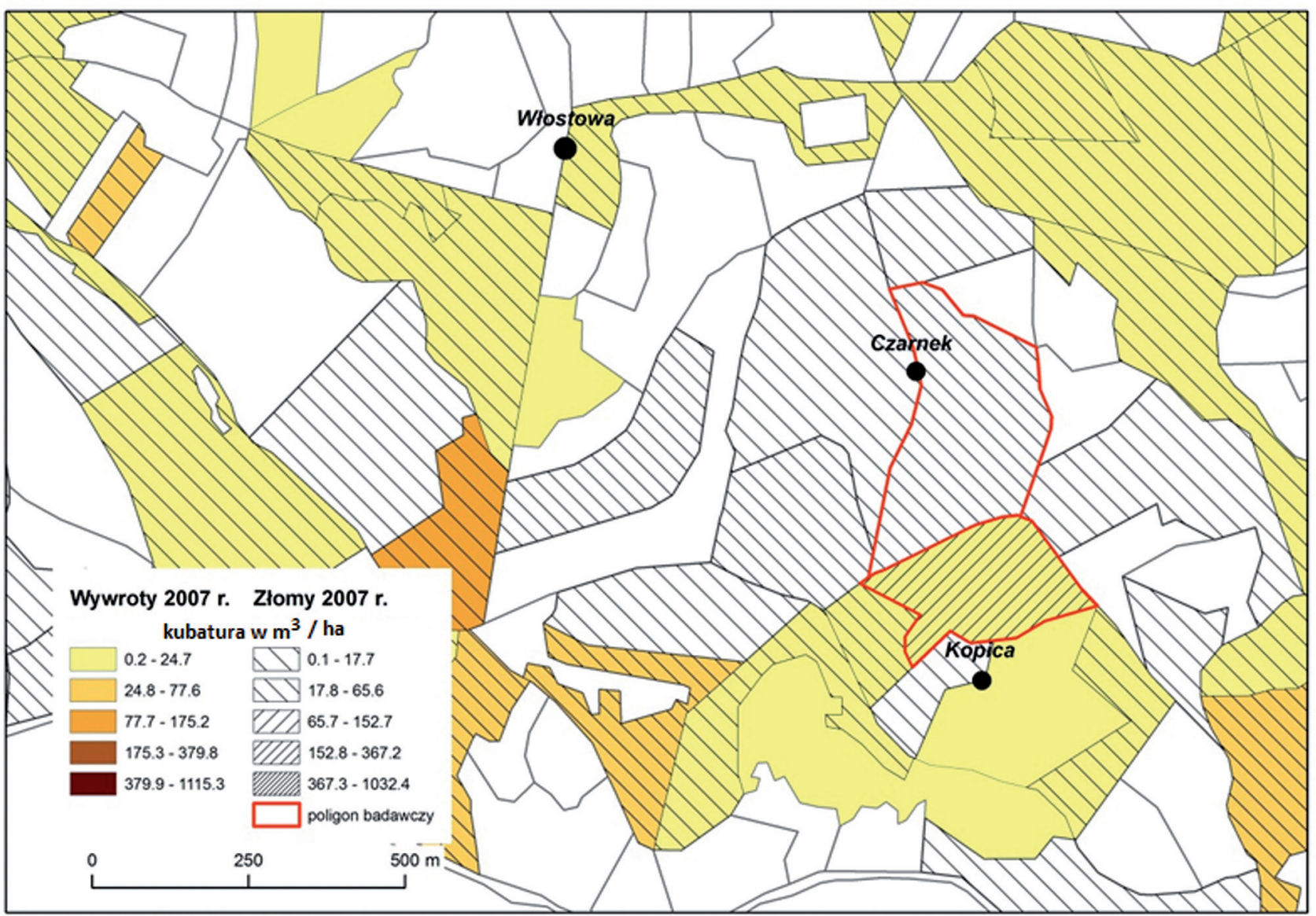

Ryc. 12. Szkody w roku 2007 w obrębie poligonu badawczego i okolicach w podziale na wywroty (wiatrowały) i złomy (wiatrołomy) (na podstawie Leśnej Mapy Numerycznej i bazy SILP)

Fig. 12. Forest damage in the study site and its closest neighbourhood in 2007 shown as uprootings and broken trees (based on Forest Digital Map and SILP database) 
no tylko drzewa złamane, co może wskazywać na o wiele lepsze zakorzenienie drzew w tym miejscu (ryc. 12). W roku 2008 nastąpił natomiast na jego stokach całkowity rozpad drzewostanu, gdzie w sierpniu tego samego roku doszło do pożaru, prawdopodobnie przez nieuwagę turystów. Był to również wynik dużego nagromadzenia suchej masy drewna na bardzo małej powierzchni. Na Kopicy zanotowano tylko minimalne zniszczenia $\mathrm{z}$ powodu wykrotów do $25 \mathrm{~m}^{3} \mathrm{ha}^{-1}$, ale bardzo duże $\mathrm{z}$ powodu złomów do $153 \mathrm{~m}^{3} \mathrm{ha}^{-1}$.

Zgodnie z założeniem przyjętym przez Bruchwald i Dmyterko $(2010,2012)$ na ryc. 10 pokazano sumę wykrotów i złomów wraz z posuszem. Posusz został uwzględniony ponieważ:

- w roku 2008 stanowił on dużą część pozyskanego drewna, ale genetycznie związany był ze zniszczeniami spowodowanymi przez huraganowy wiatr w roku 2007;

- informacja na temat posuszu jest istotna $\mathrm{z}$ punktu widzenia ryzyka zniszczeń w kolejnych latach pod warunkiem częściowego przetrwania drzewostanu. W takiej analizie stopień uszkodzenia drzewostanów w przeszłości uważany jest za główny czynnik determinujący ryzyko powstania szkód w przyszłości.

\section{Zmiany w zalesieniu - implikacje geomorfologiczne}

W obrębie obszaru szczegółowych badań terenowych na stokach Kopicy i Czarnka bezpośrednim efektem procesu saltacji wykrotowej była zmiana w miąższości pokryw glebowo-zwietrzelinowych, z jednej strony zmniejszając ich grubość w obrębie zagłębień (do $90 \mathrm{~cm}$ głębokości), a drugiej nadbudowując je (karpy, formy akumulacyjne). Wysokość niektórych karp dochodziła do $200 \mathrm{~cm}$, a ich

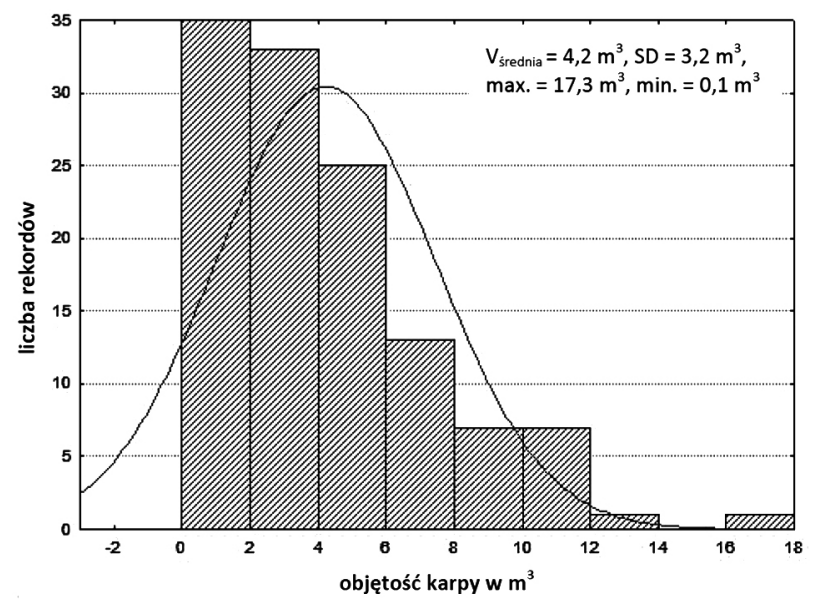

Ryc. 13. Objętość pomierzonych karp na stokach Kopicy i Czarnka pokazana jako funkcja gęstości

Skróty: Vśrednia = średnia objętość karpy, SD = odchylenie standardowe

Fig. 13. The volume of measured root plates at Kopica and Czarnek study sites shown as a probability density function Abbreviations: Vśrednia $=$ mean root plate volume, $\mathrm{SD}=$ standard deviation

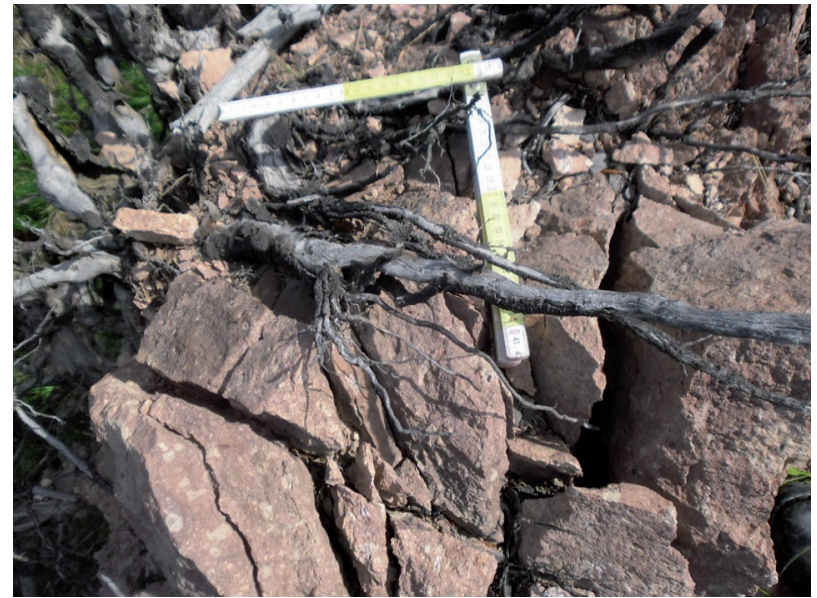

Ryc. 14. Spękana skała podłoża w jednej z karp zalegających na stoku Kopicy, Góry Suche, 2012

Fig. 14. Fractured bedrock in a root plate recorded on the Kopica hillslope, Suche Mts., 2012

średnia objętość wyniosła 4,2 $\mathrm{m}^{3}$ (ryc. 13). Skartowano 200 form, w tym 149 o pełnych wymiarach (szerokości, wysokości i miąższości), co pozwoliło na obliczenie ich objętości. W przypadku wyniesienia wraz z bryłą korzeniową spękanego i zwietrzałego podłoża skalnego, czynnik biotyczny doprowadził poprzez proces saltacji wykrotowej do gwałtownej migracji frontu wietrzenia, bez zmian chemicznych skały (ryc. 14). W obrębie poligonu Kopicy stwierdzono trzy takie przypadki. Jest to jeden z najbardziej klarownych przykładów wietrzenia biomechanicznego, choć działającego punktowo.

W obszarze badań nastąpiło wzbogacenie powierzchni stoku w znaczną ilość fragmentów skalnych frakcji gruzowej $(<7,5 \mathrm{~cm})$ i kamienistej $(7,5-20 \mathrm{~cm})$. Jest to przede wszystkim bezpośredni efekt działania procesu saltacji wykrotowej, ale również efekt cech podłoża skalnego i pokryw stokowych tworzących siedliska dla drzew ulegających powaleniu. Fragmenty skalne zostały wyniesione w karpach powalonych drzew. Średnia wartość dla najdłuższej krawędzi nie przekroczyła $20 \mathrm{~cm}$, najczęściej oscylując wokół $16 \mathrm{~cm}$. W czterech przypadkach stwierdzono odłamki skalne, których najdłuższa krawędź przekroczyła $50 \mathrm{~cm}$ (dwa na stoku i dwa nadal tkwiące w karpie). Największy z fragmentów osiągnął $70 \mathrm{~cm}$ długości. Jedną z ważniejszych cech analizowanych fragmentów skalnych jest ich niski stopień zwietrzenia chemicznego, ostre krawędzie i bardzo duża twardość stwierdzona organoleptycznie w terenie.

W obszarze badań powstały również specyficzne bruki stokowe, głównie na stokach Czarnka, gdzie efekt ten został zwiększony przez wypalenie pni i systemów korzeniowych karp w trakcie pożaru w 2008 r. Sytuacja taka dotyczyła dwóch konfiguracji: 1) w obrębie naruszonych powierzchni stoku, gdzie są one częścią odkrytej po powaleniu drzewa pokrywy stokowej powstałej in situ, oraz 2) poniżej form akumulacyjnych, gdzie są efektem redystrybucji materiału mineralnego usuwanego z karp wykrotów. W siedmiu przypadkach na 200 zmierzonych karp doszło do całkowitego zdarcia regolitu i wyeksponowania spęka- 
nej skały macierzystej. Takie przypadki najczęściej obserwowano na północnym, bardzo stromym stoku Kopicy, gdzie pokrywa stokowa jest nieznacznej miąższości.

\section{Dyskusja}

Gwałtowne zjawiska natury meteorologicznej tj. huraganowy wiatr powodują zmiany (zaburzenia) w pokrywach stoków zalesionych w efekcie powstawania wiatrowałów (drzew przewracanych z korzeniami), w procesie nazywanym w nomenklaturze geomorfologicznej saltacją (denudacją) wykrotową (Gerlach 1960, Kotarba 1970). W Sudetach zjawisko to miało szczególnie intensywny i powszechny charakter w trakcie orkanu Cyryl 18-19 stycznia 2007 r. (Pawlik, 2012a), obejmując swoim zasięgiem również Nadleśnictwo Wałbrzych i Góry Suche leżące w jego obrębie. W trakcie tego orkanu w Nadleśnictwie Wałbrzych powstały głównie wiatrowały (wywroty), ale ze względu na zakres zniszczeń duża ich część została pozyskana dopiero w roku następnym, jako posusz (ryc. 5). Odmiennie sytuacja wyglądała na stokach Czarnka i Kopicy, gdzie przeważały wiatrołomy (ryc. 12), wyrażone jako kubatura pozyskanego drewna. Jednakże

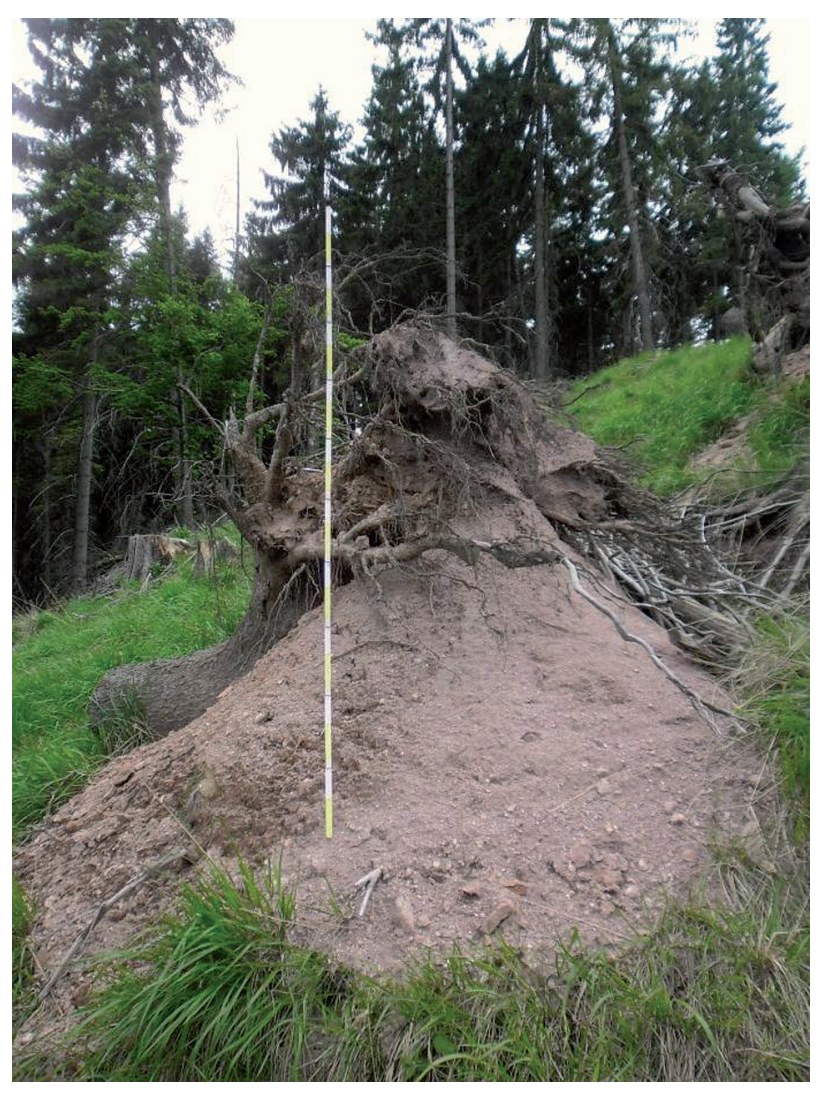

Ryc. 15. Przykład formy akumulacyjnej w kształcie stożka zbudowanej z materiału pylasto-gruzowego, rozwiniętej obok i poniżej karpy powalonego drzewa; wschodni stok Kopicy, Góry Suche, 2012

Fig. 15. An example of conical shape accumulation form, built of silt-gravel material and developed beside and below a root plate of uprooted tree; eastern slope of Kopica, Suche Mts., 2012. w trakcie prac terenowych skartowano 200 przypadków powalonych drzew, w tym 149 o w pełni wyeksponowanych karpach i średniej objętości 4,2 $\mathrm{m}^{3}$ (ryc. 13 i 15) (Pawlik, 2013a, 2014).

Dodatkowo zarejestrowano formy akumulacyjne, które są efektem posaltacyjnej dynamiki morfologii wykrotowej na jej wczesnym etapie ewolucji (fig. 15). Procesy degradacyjne działają od początku wyeksponowania karpy na powierzchnię stoku, przy jednoczesnym powolnym rozkładzie systemu korzeniowego i podtrzymującego go pnia. W ten sposób najczęściej powstają kopce posaltacyjne (np. Šamonil i in. 2010). Jednakże w wyniku ruchów grawitacyjnych (osypywania, odpadania), spłukiwania i rozbryzgu, materiał glebowo-zwietrzelinowy podlega transportowi i akumulacji w sąsiedztwie karpy lub poniżej jej miejsca zalegania na stoku, tworząc często formy o kształcie stożków, pasów i pól. W przypadku przewagi większych frakcji (szkieletowych, $>2 \mathrm{~mm}$ ) powinny być one traktowane jako jeden z etapów tworzenia się bruków stokowych, pasów kamienistych, wstęg rumoszu i rumoszy skalnych, choć w tym przypadku ich geneza wykracza poza tradycyjne ujęcie tego zagadnienia (Klimaszewski 1981). Materiał skalny z karp ulega transportowi również do zagłębień, natomiast od strony pnia często ulega akumulacji na pniu, nie osiągając poziomu gruntu. W przypadku podrostów młodych drzew rosnących poniżej karpy często są one zasypywane materiałem skalnym, przez co mogą ulec wygięciu lub obumarciu.

Karpy posaltacyjne zatrzymują materiał pokryw stokowych na okres kilku lub nawet kilkunastu lat na pewnej wysokości nad poziomem gruntu. W tym czasie tak wyniesiona partia pokryw glebowych jest „odcięta” od powierzchni stoku, co definitywnie zmienia kierunek pedogenezy (aż do momentu całkowitego zrównania karpy) i hamuje dalszy transport materiału glebowego. Fragmenty skalne różnej frakcji zostają wyniesione i wyeksponowane na bezpośrednie działanie warunków meteorologicznych na wysokość nawet powyżej $2 \mathrm{~m}$ n.p.g. Może wtedy dochodzić do selektywnej depozycji materiału w zagłębieniach (Small i in. 1990). Jednakże degradacja karpy następuje najszybciej podczas uderzenia w nią sąsiedniego drzewa. Materiału glebowy deponowany jest wtedy poniżej karpy na stoku i w zagłębieniu w sposób gwałtowny i chaotyczny.

\section{Wnioski i podsumowanie}

Informacje na temat wiatrowałów i wiatrołomów pozwoliły na analizę przekształceń lasów w Nadleśnictwie Wałbrzych oraz w obrębie poligonu badawczego w Górach Suchych. W artykule przedstawiono możliwość implementacji danych zbieranych na potrzeby leśnictwa w badaniach geomorfologicznych. Jednocześnie wskazano na ograniczenia w wykorzystaniu tych informacji. Kubatura pozyskanego drewna $\mathrm{z}$ wywrotów i złomów nie daje pełnego obrazu przekształceń drzewostanów, tym bardziej ocena zmian w systemie stokowym wymaga 
przeprowadzenia konwencjonalnych badań terenowych. Przewodnim argumentem za wykorzystaniem danych archiwizowanych przez Lasy Państwowe jest ich zasięg przestrzenny i czasowy. Obejmują one wszystkie nadleśnictwa w kraju, w tym w formie cyfrowej dostępne są zestawienia od roku 2004. Jest to zatem najbardziej kompletna baza danych, która, choć niepełna z punktu widzenia analiz geomorfologicznych, po części oddaje dynamikę procesu saltacji wykrotowej i może być cennym tłem dla dalszych analiz. Pozwala to np. na wstępną selekcję obszaru planowanych szczegółowych badań terenowych w oparciu o poligony o największej intensywności powstania wiatrowałów; gdzie pozyskano największą objętość drewna z wiatrowałów.

Szereg efektów powierzchniowych na stokach Gór Suchych, które są bezpośrednio lub pośrednio powiązane z procesem saltacji wykrotowej nie pozostawia wątpliwości, że geoekosystem stoków zalesionych jest środowiskiem dynamicznym podlegającym m.in. takim zaburzeniem zewnętrznym jak huraganowy wiatr. Przykładowo stawia to pod znakiem zapytania możliwość przetrwania struktur peryglacjalnych (soliflukcyjnych) w obrębie zalesionych stoków sudeckich. Drzewa zakorzeniające się do głębokości nawet jednego metra i często podlegające wykrotowaniu są ważnym czynnikiem bioturbacyjnym pokryw stokowych i gleb.

\section{Podziękowania}

Składam serdeczne podziękowania prof. Piotrowi Migoniowi oraz dwóm anonimowym recenzentom, których uwagi w sposób istotny wpłynęły na ostateczną wersję artykułu. Dziękuję Łukaszowi Longoszowi za korektę abstraktu i podpisów do rycin w języku angielskim. Dziękuję również następującym instytucjom za udostępnienie materiałów źródłowych: Regionalnej Dyrekcji Lasów Państwowych we Wrocławiu, Biuru Urządzania Lasów i Geodezji Leśnej w Brzegu, Instytutowi Badawczemu Leśnictwa w Sękocinie Starym oraz Nadleśnictwu Wałbrzych. Badania prowadzone były dzięki grantowi Urzędu Marszałkowskiego Województwa Dolnośląskiego (Grant Plus), współfinansowanemu ze środków Unii Europejskiej w ramach Europejskiego Funduszu Społecznego (Program Operacyjny Kapitał Ludzki). Część badań wykonana została w ramach grantu MNiSW (NN 306032940).

\section{Literatura}

Awdankiewicz M., 1999. Volcanism in a late Variscan intramontane trough: Carboniferous and Permian volcanic centres of the Intra-Sudetic Basin, SW Poland. Geologia Sudetica 32: 13-47.

Beyer H.L., 2004. Hawth's Analysis Tools for ArcGIS. Online: http:// www.spatialecology.com/htools.

Birot P., 1966. General physical geography. George G. Harper \& Co. Ltd, London, UK.

Brázdil R., 1998. Meteorological extremes and their impacts on forests in the Czech Republic. In: M. Beniston, J.L. Innes (eds.), The impacts of Climate Variability on Forests, Springer-Verlag Berlin, Heidelberg, New York: 19-47.

Brázdil R., Dobrovolný P., Štekl J., Kotysa O., Valášek H., Jež J., 2004. History of weather and climate in the Czech Lands VI: Strong winds. Masaryk University, Brno.

Bruchwald A., Dmyterko E., 2010. Metoda określania ryzyka uszkodzenia drzewostanu przez wiatr. Leśne Prace Badawcze 71(2): 165-173.

Bruchwald A., Dmyterko E., 2012. Ryzyko powstawania szkód w drzewostanach poszczególnych nadleśnictw Polski. Sylwan 156(1): 19-27.

Dąbrowska K., 2009. The morphogenetic impact of the bora type wind $\left(19^{\text {th }}\right.$ November 2004) on the relief of Danielov dom area (The High Tatras). Landform Analysis 11: 5-10.

Dobrowolska D., 2010. Rola zaburzeń w regeneracji lasu. Leśne Prace Badawcze 71: 391-405.

Everham E.M., Brokaw N.V., 1996. Forest damage and recovery from catastrophic wind. The Botanical Review 62(2): 113-185.

Faliński J.B., Falińska K., 1986. Vegetation dynamics in temperate lowland primeval forests: ecological studies in Białowieża forest. Dordrecht: W. Junk.

Fink A.H., Brücher T., Ermert V., Krüger A., Pinto J.G., 2009. The European storm Kyrill in January 2007: synoptic evolution meteorological impacts and some considerations with respect to climate change. Natural Hazards and Earth System Sciences 9: 405-423.

Gardiner, B.; Blennow, K.; Carnus, J.M.; Fleischner, P.; Ingemarson, F.; Landmann, G.; Lindner, M.; Marzano, M.; Nicoll, B.; Orazio, C.; Peyron, J.L.; Reviron, M.P.; Schelhaas, M.; Schuck, A.; Spielmann, M.; Usbeck, T., 2010. Destructive storms in European Forests: Past and Forthcoming Impacts. Final report to European Commission DG Environment, Joensuu, Finland: European Forest Institute.

Gerlach T., 1960. W sprawie genezy kopczyków ziemnych na Hali Długiej w Gorcach. Przegląd Geograficzny 32(1-2): 86-93.

Gerlach T., 1976. Współczesny rozwój stoków w Polskich Karpatach Fliszowych. Prace Geograficzne IGiPZ PAN, 122.

Głowicki B., 2005. Klimat Karkonoszy. W: M.P. Mierzejewski (red.), Karkonosze. Przyroda nieożywiona i człowiek, Wydawnictwo Uniwersytetu Wrocławskiego, Wrocław: 381-397.

Jenness J., 2011. DEM Surface Tools - An ArcGIS Extension for Analysing Raster Elevation Datasets. Jenness Enterprises, USA. Online: http://www.jennessent.com/arcgis/surface_area.htm.

Jewuła E., 1974. Regionalizacja szkód powodowanych przez wiatry w drzewostanach górskich i podgórskich Południowej Polski. Sylwan 118(10): 54-63.

Jońca E., 1987. Projektowany rezerwat przyrody nieożywionej Jeleniec w Górach Suchych w Sudetach Środkowych. Chrońmy Przyrodę Ojczystą 43(2): 61-68.

Klimaszewski M., 1981. Geomorfologia. PWN, Warszawa.

Kosiba A., 1948. Klimat Ziem Śląskich, Zagadnienia gospodarcze Śląska, Seria 2, 9, Wydawnictwo Instytutu Śląskiego, Katowice-Wrocław.

Kotarba A., 1970. The morphogenetic role of foehn wind in the Tatra Mts. Studia Geomorphologica Carpatho-Balcanica 4: 171-188.

Mała Encyklopedia Leśna, 1991, (red.) S. Kocięcki, A. Zdanowski, A. Kolk, S. Rzadkowski, R. Sobczak, PWN Warszawa.

Migoń P., Pánek T., Malik I., Hrádecký J., Owczarek P., Šilhán K., 2010. Complex landslide terrain in the Kamienne Mountains, Middle Sudetes, SW Poland. Geomorphology 124: 200-214.

Minár J., Faltan V., Bánovský M., Damankošová Z., Kožuch M., 2009. Influence of site conditions on the windstorm impact: a case study of the High Tatras foothills in 2004. Landform Analysis 10: 95-101.

Pawlik Ł, 2009. Znaczenie saltacji wykrotowej w kształtowaniu rzeźby stoku. Czasopismo Geograficzne 80(3): 130-146.

Pawlik Ł., 2012a. Zniszczenia w lasach sudeckich pod wpływem orkanu Cyryl (18-19.01.2007) - implikacje historyczne i regionalne. Przegląd Geograficzny 84(1): 53-75.

Pawlik Ł., 2012b. Przekształcenia powierzchni stokowych w Sudetach w wyniku procesu saltacji wykrotowej. Landform Analysis 20: 7994.

Pawlik Ł., 2013a. Remodelling of slope surface in the Suche Mts., SW Poland, as an effect of catastrophic windthrow caused by the Kyrill storm in 2007. In: A. Decaulne (ed.), Arbres \& dynamiques, Presses Universitaires Blaise Pascal, University of Clermont-Ferrand 2, France: 49-69. 
Pawlik Ł., 2013b. Implikacje procesu saltacji wykrotowej w biomechanicznym przekształcaniu pokryw stokowych i mikrorzeźby stoku w piętrze regla górnego Karkonoszy Polskich, Prace Geograficzne UJ 135: 41-56.

Pawlik Ł., 2013c. The role of trees in the geomorphic system of forested hillslopes - a review. Earth-Science Reviews 126: 250-265.

Pawlik Ł., 2014. Biogenic imprint on hillslopes in the Sudety Mts. - origin and consequences of the tree uprooting process, Studia Geomorphologica Carpatho-Balcanica 48: 17-34.

Peterson C.J., 2000. Catastrophic wind damage to North American forests and the potential impact of climate change. The Science of the Total Environment 262: 287-311.

Plan Urządzania Lasu dla Nadleśnictwa Wałbrzych, 2009. Opis ogólny lasów Nadleśnictwa, Biuro Urządzenia Lasów i Geodezji Leśnej oddział w Brzegu, RDLP Wrocław, Lasy Państwowe. Online: http://bip. lasy.gov.pl/pl/bip/dg/rdlp_wroclaw/.
Rojan E., 2010. Rola bardzo silnego wiatru w przekształcaniu rzeźby terenu w piętrze leśnym gór, na przykładzie wiatrowału w słowackich Tatrach Wysokich. Czasopismo Geograficzne 81 (1-2): 103-123.

Schelhaas M-J., Nabuurs G-J., Schuck A., 2003. Natural disturbances in the European forests in the $19^{\text {th }}$ and $20^{\text {th }}$ centuries. Global Change Biology 9: 1620-1633.

Small T.W., Schaetzl R.J., Brixie J.M., 1990. Redistribution and mixing of soil gravels by tree uprooting. Professional Geographer 42(4): 445-457.

Szwagrzyk J., 2000. Rozległe naturalne zaburzenia w ekosystemach leśnych: ich zasięg, charakter i znaczenie dla dynamiki lasu. Wiadomości Ekologiczne 46(1): 3-19.

Šamonil P., Král K., Hort L., 2010. The role of tree uprooting in soil formation: a critical literature review. Geoderma 157: 65-79. 